Pesq. Vet. Bras. 36(6):545-550, junho 2016 DOI: $10.1590 / \mathrm{S} 0100-736 \mathrm{X} 2016000600014$

\title{
B-Mode and pulsed Doppler sonography of kidney in healthy sheep according to age $^{1}$
}

\author{
Bianca P. Santarosa ${ }^{2 *}$, Danilo O.L. Ferreira ${ }^{3}$, Alexandra F. Belotta ${ }^{4}$, Adriano Dias ${ }^{5}$, \\ Maria J. Mamprim ${ }^{4}$ and Roberto C. Gonçalves ${ }^{2}$
}

\begin{abstract}
Santarosa B.P., Ferreira D.O.L., Belotta A.F., Dias A., Mamprim M.J. \& Gonçalves R.C. 2016. B-Mode and pulsed Doppler sonography of kidney in healthy sheep according to age. Pesquisa Veterinária Brasileira 36(6):545-550. Departamento de Clínica Veterinária, Faculdade de Medicina Veterinária e Zootecnia, Universidade Estadual Paulista, Campus Botucatu, Distrito de Rubião Junior s/n, Botucatu, SP 18618-970, Brazil. E-mail: biancasantarosavet@gmail.com

There is no standardization in the literature of kidney length in sheep at different ages, as there are few studies about the access with the Doppler triplex ultrasound for the renal vascularization in this species. Eighty healthy sheep of three age groups of Ile de France and White Dorper breed were used: 20 lambs, 30 yearlings and 30 adults ( 8 rams and 22 ewes). Renal healthiness of the animals was confirmed by serum biochemical tests of urea and creatinine, and by observation of renal architecture with conventional ultrasound, besides measurement of vital parameters. A portable ultrasound (My LabTM30 Vet Gold Esaote ${ }^{\circledR}$, Esaote Healthcare) device was used, with a convex transducer with $3.5 \mathrm{MHz}$ frequency. After identification of the kidneys in two-dimensional mode, the measurement of length in the sagittal section was performed in all sheep $(\mathrm{n}=80)$. Then color Doppler was activated for visualization of renal and interlobar arteries of the right kidney, and the resistivity index (RI) of the yearlings $(n=30)$ and ewes $(n=22)$ was measured. Biochemical tests remained within normal limits and renal architecture was preserved. The values of the right and left renal length were different between the groups, increasing with age $(4.34 \mathrm{~cm}$ and $4.31 \mathrm{~cm}$ in lambs; $6.08 \mathrm{~cm}$ and $6.23 \mathrm{~cm}$ in yearlings; $7.57 \mathrm{~cm}$ and $7.37 \mathrm{~cm}$ in adults, respectively). Median values of RI of the renal artery were statistically different $(p<0.05)$ between the groups of yearlings $(0.57)$ and ewes $(0.52)$. The median RI of the interlobar artery was similar in yearlings (0.58) and ewes (0.54).
\end{abstract}

INDEX TERMS: Creatinine Doppler, kidneys, sheep, ultrasonography.

RESUMO.- [Ultrassonografia Modo-B e Doppler pulsado dos rins de ovinos hígidos de acordo com a idade.] Não há na literatura padronização do comprimento renal de

\footnotetext{
${ }^{1}$ Received on Setember 17, 2015.

Accepted for publication on April 3, 2016.

${ }^{2}$ Departamento de Clínica Veterinária, Faculdade de Medicina Veterinária e Zootecnia (FMVZ), Universidade Estadual Paulista (Unesp), Campus Botucatu, Distrito de Rubião Junior s/n, Botucatu, SP 18618-970, Brazil. *Corresponding author: biancasantarosavet@gmail.com

${ }^{3}$ Coordenatoria de Assistência Técnica Integrada (CATI), Secretaria de Agricultura e Abastecimento do Estado de São Paulo, Casa de Agricultura, Av Odon Pessoa de Albuquerque 788, Centro, Agudos, SP 17120-000, Brazil.

${ }^{4}$ Departamento de Reprodução Animal e Radiologia Veterinária, FMVZ-Unesp, Campus Botucatu, District of Rubião Junior s/n, Botucatu, SP 18618-970, Brazil.

${ }^{5}$ Departamento de Saúde Pública, Faculdade de Medicina de Botucatu (FMB), Unesp, Campus Botucatu, District of Rubião Junior s/n, Botucatu, SP 18618-970, Brazil.
}

ovinos, em diferentes idades, assim como existem poucos trabalhos sobre a vascularização renal nesta espécie. Utilizaram-se no total 80 ovinos hígidos de três faixas etárias, das raças Ile de France e White Dorper: 20 cordeiros, 30 borregos e 30 adultos ( 8 carneiros e 22 ovelhas). A higidez renal dos animais foi comprovada por exames bioquímicos séricos de ureia e creatinina e pela observação da arquitetura renal. Utilizou-se aparelho de Ultrassom portátil (My LabTM30 Vet Gold Esaote ${ }^{\circledR}$, Esaote Healthcare), com transdutor convexo de frequência de 3,5MHz. Após identificação dos rins no modo bidimensional, foi realizada a mensuração do comprimento no corte sagital em todos os ovinos. Em seguida, Doppler colorido foi ativado para visualização das artérias renal e interlobar do rim direito, e mensurou-se o índice de resistividade dos borregos $(\mathrm{n}=30)$ e ovelhas $(\mathrm{n}=22)$. Os exames bioquímicos permaneceram dentro da normalidade e a arquitetura renal estava preservada. Os 
valores do comprimento renal direito e esquerdo foram diferentes entre os grupos, sendo crescente conforme a idade (4,34 e 4,31 em cordeiros, 6,08 e 6,23 em borregos, 7,57 e 7,37 em adultos). As medianas do IR da artéria renal foi estatisticamente diferente $(\mathrm{p}<0,05)$ entre os grupos dos borregos $(0,57)$ e ovelhas $(0,52)$. A mediana do IR da artéria interlobar não apresentou diferença entre borregos $(0,58)$ e ovelhas $(0,54)$.

TERMOS DE INDEXAÇÃO: Creatinina, Doppler, ovinos, ultrassonografia.

\section{INTRODUCTION}

Ultrasonography (US) has been increasingly used in clinical and surgical practice of large animals (Floeck 2009). Although most of ultrasound examinations in production animals are targeted for early pregnancy diagnosis, knowledge of the US for the digestive, respiratory, hepatobiliary, cardiovascular and urinary systems increased considerably over the last 20 years (Streeter \& Step 2007, Acorda et al. 2009).

Physical examination is essential for detection of changes in the system to be studied (Cartee et al 1980, Widmer et al. 2004). However, the use of complementary diagnostic methods such as ultrasound, can be of great help in the diagnosis of certain diseases. The ultrasound examination is performed safely, without risk to the animal health, and it even allows obtaining early data to laboratory abnormalities (Floeck 2009).

In sheep, the US has been widely used in the evaluation of urinary tract lesions (Scott 2012, Scott 2013, Ferreira et al. 2014). Its ability to detect radiolucent stones makes this an advantageous diagnostic method, instead of the radiographic examination (Scott 2013). Furthermore, the ultrasound enables the recognition of possible complications secondary to obstruction of urinary flow, such as pyelonephritis, hydronephrosis, cystitis and uroperitoneo and other lesions such as renal cysts and abscesses, presence of tumors and congenital abnormalities of the urinary tract (Cartee et al. 1980, Scott 2000, El-Kammar et al. 2012, Scott 2012).

The resistivity index (RI) corresponds to the measurement of arterial vascular resistance and is calculated by the peak systolic velocity and final diastolic velocity obtained in the spectral trace with pulsed Doppler (Koma et al. 2006). It can be used in monitoring changes in the perfusion resistance of the renal parenchyma (Silva et al. 2008) and high values were found in acute tubular necrosis, renal ischemia, endotoxemia, tubulointerstitial disease and urethral obstruction (Lee et al. 2014). Normal values have already been determined for human species (Morrow et al. 1996), dogs (Nyland et al. 1993) and cats (Finn-Bodner \& Hudson 1998).

Although many papers discussed changes in the urinary system of sheep, mainly related to obstructive urolithiasis (Scott 2000, Scott 2012, Scott 2013), there is no in the literature a normal pattern of ultrasound characteristics of the kidney with the conventional way according to experiments by Floeck et al. (2013) in the spleen of healthy sheep.
In the literature there are a few data on the reference values of RI of renal and interlobar arteries of healthy sheep, due to the lack of studies using the Doppler tool as diagnostic (Biricik et al. 2003). Most of the works using this resource in sheep is related to reproductive aspects of the species (Figueira et al. 2015) or the experimental studies for new medical knowledge for the benefit of human patients (Calzavacca et al. 2015).

The rationale for this study relates to the relevance of ultrasonography for diagnosis of urinary system changes in sheep and literary scarcity of data regarding the normal range, particularly concerning RI values. In healthy sheep, divided into three age groups (lambs, yearlings and adults), it was intended to: establish standard for the size of the length of the kidneys for US; establish quantitative standard for RI of renal and interlobar arteries of the right kidney by US Doppler; compare the results between the groups to check variations in these characteristics with age. So, this study give more data for diagnosis changes in urinary tract in sheep.

\section{MATERIALS AND METHODS}

Animals. Three age groups of sheep were formed for the study: lambs (up to a month), yearlings (up to one year old) and adult (more than two years of age). 80 healthy sheep were used, of Ile de France and White Dorper breeds: 20 lambs (seven to 21 days of age, average weight $9 \mathrm{~kg}$ ), ten males and ten females; 30 male yearlings (three to four months of age; average weight $25 \mathrm{~kg}$ ); 30 adults (two to five years), eight rams (average weight $100 \mathrm{~kg}$ ) and 22 ewes (average weight $60 \mathrm{~kg}$ ), in the postpartum period.

The animals were from Cabanha Chico Borborema, located in São Manuel/SP city, which were created under semi-intensive management, were in the pasture (Cynodon dactylon), and received silage and commercial feed in the trough, and mineral salt and water ad libitum.

Serum biochemical tests (urea and creatinine). Renal healthiness of the animals has been proven, and the absence of clinical symptoms by measuring the vital parameters, by serum biochemical tests of urea and creatinine and by observation of renal architecture through ultrasound examination. Blood samples were collected from the jugular vein in vacuum tubes without anticoagulant (BD Vacutainer®, BD Medical, Curitiba/PR, Brazil). After clot retraction, the sample was centrifuged to obtain serum at $250 \mathrm{~g}$ for ten minutes (Combate Celm ${ }^{\circledR}$ Cia. Equipadora de Laboratórios Modernos, Barueri/SP, Brazil). Serum portions of $2 \mathrm{~mL}$ were separated into plastic tubes (Eppendorf do Brasil Ltda, São Paulo/P, Brazil) and stored at $-20^{\circ} \mathrm{C}$. Laboratory measurements were made by commercial kits (Katal ${ }^{\circledR}$ Biotecnológica Ind. Com. Ltda, Belo Horizonte/MG, Brazil), at one time, in the Clinical Pathology Service of the Department of Veterinary Clinics of FMVZ/ Unesp, Botucatu. The methods used were enzymatic colorimetric, for determining the concentration of urea; kinetic and colorimetric, for creatinine, with spectrophotometric reading (Aparelho SB-190 Celm ${ }^{\circledR}$ Cia, Equipadora de Laboratórios Modernos, Barueri/SP, Brazil). The urea and creatinine values were compared to the normal range for the species proposed by Kaneko et al. (2008).

B-mode sonography. A portable ultrasound device (My Lab $^{\mathrm{TM}} 30$ Vet Gold Esaote ${ }^{\circledR}$, Esaote Healthcare do Brasil, São Paulo/ SP, Brazil) was used, with the convex transducer of $3.5 \mathrm{MHz}$ frequency. For the ultrasound, the sheep were contained manually in the left lateral position for the right kidney (RK) access. For better image quality, the animals were shorn, and in the contact 
region with the transducer previous trichotomy was performed. For kidney viewing the transducer was located in the caudal edge of the rib cage, in the dorsal region of paralombar fossa, ventral to the lumbar transverse processes. The RK was visualized juxtaposed to the caudal pole of the liver (Scott \& Sargison 2010). In the left kidney (LK) by the presence of the rumen, the transducer was directed cranially below the last rib. After identification of the kidneys in two-dimensional mode, there was the measurement of renal length in the sagittal section, besides the observation of the organ architecture (Fig.1).

Pulsed Doppler sonography. Only RK was examined for the visualization of vascularization, because LK was hampered by the rumen. After kidney identification in the two-dimensional mode, color Doppler was activated for viewing the interlobar and renal arteries (Fig.2). The sample volume of the pulsed Doppler was then positioned first on the renal artery and later on the interlobar insonation at an angle of less than 60 , yielding at least three waves of the arterial spectral trace. The RI was calculated automatically by the equipment itself after manual delimitation of the peak systolic velocity and final diastolic velocity. This procedure was repeated two more times and the average RI of each artery was obtained for each animal.

Statistical analysis. Data were analyzed by IBM SPSS Statistics software, v.21, with a significance level of $95 \%(\mathrm{p}<0.05)$. Continuous variables, serum biochemistry tests (urea and creatinine) and the length of the kidneys due to the nonparametric distribution of responses, were analyzed among the three experimental groups (Group 1, 2 and 3) by the Kruskal-Wallis test to identify differences. When there was a statistically significant difference, it was verified by post-hoc Dunn. The RI data of the renal and interlobar arteries were analyzed using the Mann-Whitney test.

Ethical aspects. This project was approved by the Ethics Committee on Animal Use (CEUA) FMVZ-UNESP, Botucatu, under the Protocol. 188/2014.

\section{RESULTS AND DISCUSSION}

\section{Urea, creatinine and B-mode sonography}

The means, standard deviations and median values of urea, creatinine, renal length (right and left) of the three groups are shown in Table 1.

Serum urea evaluated values of lambs and adults remained within normal limits for the species of 17.12 to $42.80 \mathrm{mg} / \mathrm{dL}$, according to Kaneko et al. (2008). Regarding the average and median of urea results of yearlings, they were slightly above the reference range, but may be considered normal due to the diet being composed of high protein $(20 \%)$, since urea is directly related to protein metabolism (Ferreira et al., 2014). There was statistical difference between the groups, and the lambs had values lower than lambs and adult groups.

Serum creatinine values in all groups were below the reference values for sheep, 1.2 to $1.9 \mathrm{mg} / \mathrm{dL}$, according to Kaneko et al. (2008), which is considered normal. There was statistical difference between the groups, considering that the median for yearlings was similar to the median for lambs and adults, and these last ones were different among themselves.

The visualization of the kidneys by US was obtained successfully in the three groups, and renal architecture was preserved in all animals. In adults, it was more difficult to visualize the left kidney by the effect of reverberation produced due to the presence of gas in the rumen. However,

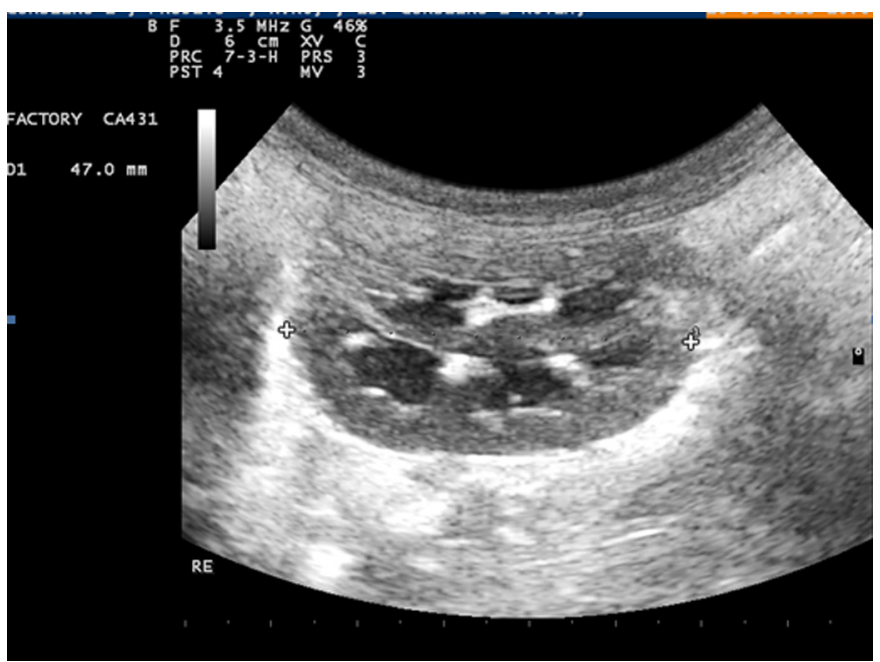

Fig.1. Measurement of length in the sagittal section of left kidney on a lamb $(4.70 \mathrm{~cm})$.

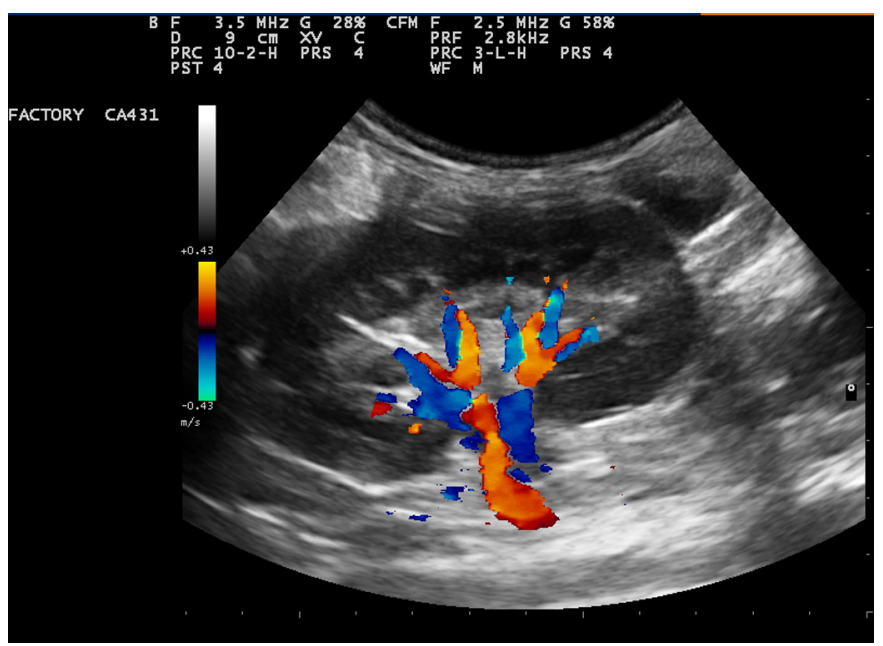

Fig.2. Renal vasculature on Color Doppler of an ewe.

Table 1. Mean ( $\bar{x})$, standard deviation (s) and median (Md) of creatinine and urea values (mg/dL) and serum length $(\mathrm{cm})$ of the right and left kidneys of sheep of the three experimental groups

\begin{tabular}{|c|c|c|c|c|c|c|}
\hline \multirow{2}{*}{$\begin{array}{l}\text { Groups/ } \\
\text { Variables }\end{array}$} & \multicolumn{2}{|c|}{ Group 1 - Lambs $(n=20)$} & \multicolumn{2}{|c|}{ Group 2- Yearlings $(n=30)$} & \multicolumn{2}{|c|}{ Group 3 - Adults $(n=30)$} \\
\hline & $\overline{\mathrm{X}} \pm \mathrm{s}$ & Md & $\overline{\mathrm{x}} \pm \mathrm{s}$ & Md & $\overline{\mathrm{X}} \pm \mathrm{s}$ & Md \\
\hline Urea & $33.58 \pm 10.60$ & $30.60^{\mathrm{a}}$ & $49.54 \pm 17.93$ & $44.25^{\mathrm{b}}$ & $43.34 \pm 11.68$ & $40.85^{b}$ \\
\hline Creatinine & $0.50 \pm 0.15$ & $0.48^{\mathrm{a}}$ & $0.72 \pm 0.16$ & $0.72^{\mathrm{ab}}$ & $0.82 \pm 0.28$ & $0.77^{\mathrm{b}}$ \\
\hline Right Kidney & $4.25 \pm 0.36$ & $4.34^{\mathrm{a}}$ & $6.02 \pm 0.47$ & $6.08^{b}$ & $7.47 \pm 0.71$ & $7.57^{\mathrm{c}}$ \\
\hline Left Kidney & $4.24 \pm 0.33$ & $4.31^{\mathrm{a}}$ & $6.23 \pm 0.71$ & $6.19^{b}$ & $7.45 \pm 0.69$ & $7.37^{c}$ \\
\hline
\end{tabular}

$\overline{a, b, c \text { Statistical difference }}(\mathrm{p}<0 ., 05)$ betweenamong the groups. 
it was possible to measure the renal length in all animals. The median length of the right and left kidneys in the three groups was statistically different from each other, and the measurement was increasing according to the age. The smallest kidney measured $3.23 \mathrm{~cm}$ in a lamb, and the highest result was $9.08 \mathrm{~cm}$, found in a ram.

Biricik et al. (2003) described the average renal length of six healthy lambs $5.56 \pm 0.16 \mathrm{~cm}$, width of $3.18 \pm 0.12 \mathrm{~cm}$ and width of the renal parenchyma $1.06 \pm 0.06 \mathrm{~cm}$. The values of renal length found by these authors were similar for sheep of the same age group studied in this work.

Ferreira et al. (2014) reported the average renal length of $6.14 \pm 0.43 \mathrm{~cm}$ of 100 sheep with five months, which was similar to the average found for the animals of the same age (yearlings) in this study.

The median values of the renal length of adult animals, and especially of the eight rams were similar to those described by Braun et al. (1992), which studied the urinary tract of 20 sheep $(8.4 \pm 0.3 \mathrm{~cm})$.

\section{Kidney architecture}

The contour of the kidneys, the echogenicity of the cortex, and the relationship cortico-medullary boundary were evaluated in all animals and they were normal, as well as the architecture was preserved, as described by Floeck (2009), for healthy animals.

\section{Pulsed Doppler sonography}

It was determined the RI values of healthy yearlings $(\mathrm{n}=30)$ and ewes $(\mathrm{n}=22)$ without difficulty (Fig.3). However, it was not possible to obtain the vascularization satisfactorily in lambs $(n=20)$ and in rams $(n=8)$. The impossibility of obtaining renal vascularization in lambs may be related to high renal vascular resistance, cited by some authors (Chang et al. 2010), or even by technical failures. As for the rams, there was no success in the exam, either, probably due to increased abdominal muscle layer and large amount of intra-abdominal fat of this group, in addition to frequency limitation of the equipment. The mean, standard deviations and medians of RI values of renal and interlobar arteries are described in Table 2.

There was statistical difference between the groups only for RI renal artery, and the ewes showed the median lower than the yearlings. But, the RI medians of interlobar artery were statistically similar among the groups.
Biricik et al. (2003) evaluated morphological characteristics of the kidneys and the RI interlobar artery of lambs with urolithiasis. The 14 animals studied were 60-75 days old, eight sick and six healthy. The mean of the RI lambs with urolithiasis was $0.81 \pm 0.017$, and of the healthy animals was $0.62 \pm 0.013$, which was similar to the values found in ewes and yearlings in this study. By comparison, the RI of the renal artery of a ram with obstructive urolithiasis and partial urethral obstruction, attended at the Clinic of Large Animal FMVZ-UNESP/Botucatu, was 0.73. This shows that values greater than 0.70 in sheep may also be considered abnormal. The same animal also presented $1.01 \mathrm{~cm}$ of dilation of the kidney pelvis, which was not observed in this animal study because they were healthy. The measurements of the length of the right kidney $(8.66 \mathrm{~cm})$ and left $(8.49 \mathrm{~cm})$ of this sheep were higher than the average of the

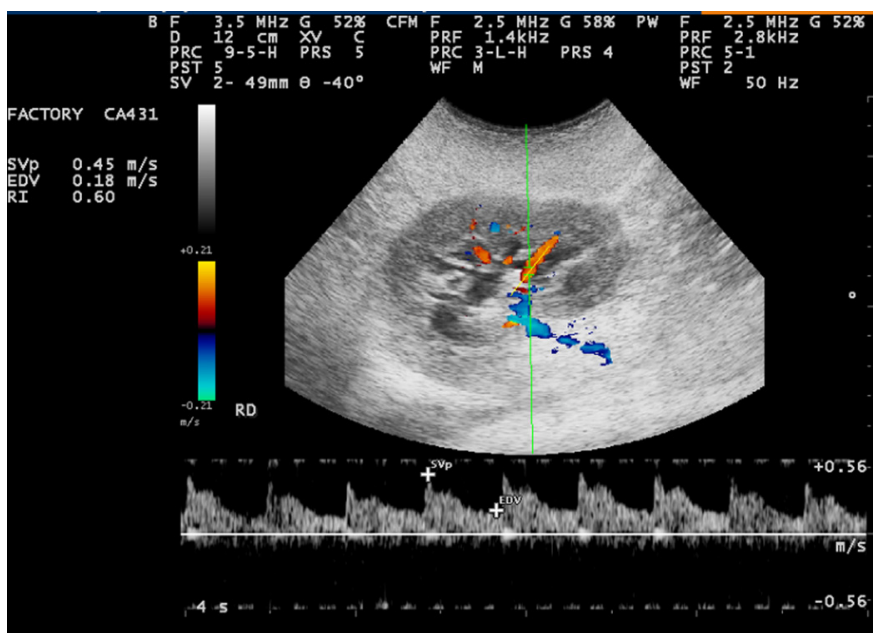

Fig.3. Normal resistivity index (0.60) and spectral trace of the interlobar artery of right kidney on pulsed Doppler of an ewe.

Table 2. Mean ( $\bar{x})$, standard deviation (s) and median (Md) of the values of the resistivity indexes (RI) of renal and interlobar arteries of sheep of the two experimental groups studied

\begin{tabular}{lccccc}
\hline \multirow{2}{*}{ Groups } & \multicolumn{2}{c}{ Group 2 - Yearlings $(\mathrm{n}=30)$} & & \multicolumn{3}{c}{ Group 3- Ewes $(\mathrm{n}=22)$} \\
\cline { 2 - 3 } \cline { 5 - 6 } RI & $\overline{\mathrm{x}} \pm \mathrm{s}$ & Md & & $\overline{\mathrm{x}} \pm \mathrm{s}$ & Md \\
\hline RI renal artery & $0.57 \pm 0.05$ & $0.57^{\mathrm{b}}$ & & $0.52 \pm 0.04$ & $0.52^{\mathrm{a}}$ \\
RI interlobar artery & $0.56 \pm 0.05$ & $0.58^{\mathrm{a}}$ & & $0.55 \pm 0.05$ & $0.54^{\mathrm{a}}$
\end{tabular}

$\overline{\text { a,b Sstatistical difference }(\mathrm{p}}<0,05)$ betweenamong the groups.

Table 3. Mean ( $\bar{x})$ and standard deviation (s) of the values of the resistivity indexes (RI) of healthy animals of others species described by authors

\begin{tabular}{lcc}
\hline Reference (authors and year) & Species (n) & RI \\
\hline Morrow et al. (1996) & Dogs ( $\mathrm{n}=22)$ & $0.61 \pm 0.06$ (renal artery) \\
Hoffmann et al. (1997) & Horses ( $\mathrm{n}=7)$ & $0.512 \pm 0.004$ (renal artery) \\
Koma et al. (2006) & Dogs (n=10) & $0.66 \pm 0.07$ (renal artery) \\
& & $0.64 \pm 0.09$ (interlobar artery) \\
Chang et al. (2010) & Dogs $<4$ months ( $\mathrm{n}=22)$ & $0.75 \pm 0.05$ (renal artery) \\
& Dogs $>5$ months ( $\mathrm{n}=33)$ & $0.65 \pm 0.05$ (renal artery) \\
Carvalho \& Chammas (2011) & Cats ( $\mathrm{n}=25)$ & $0.54 \pm 0.07$ (renal artery) \\
& & $0.52 \pm 0.06$ (interlobar artery) \\
Chetboul et al. (2012) & Dogs (n=39) & $0.62 \pm 0.05$ (interlobar artery) \\
Novellas et al. (2012) & Dogs (n=27) and Cats (n=10) & $0.62 \pm 0.04$ (renal artery)
\end{tabular}


adults cited in this paper. This ram also showed post-renal azotemia, with $11.48 \mathrm{mg} / \mathrm{dL}$ of creatinine and $203.57 \mathrm{mg} /$ $\mathrm{dL}$ of urea. The RI of renal artery increases in animals with urolithiasis obstructive because there is a change in vascular resistance caused by a uretral obstruction. In the present study, as described in the work by Biricik et al. (2003), the RI values were similar to those reported for the canine and feline species and for humans.

In Table 3 RI values of renal and interlobar arteries are described of healthy animals of different species. Morrow et al. (1996) reported that the average RI of renal artery for 22 dogs without renal lesions was $0.61 \pm 0.06$, which was slightly higher compared to the values obtained in this study. The same authors mentioned that values greater than 0.70 were found in animals with clinical diagnosis of acute renal failure and congenital dysplasia.

Novellas et al. (2012) found no difference between the RI of renal artery between the right and left kidneys of dogs and cats. The average RI of renal artery of $27 \mathrm{dogs}$ and of 10 cats studied was $0.62 \pm 0.04$, which is also close to the values of this study with sheep.

Carvalho \& Chammas (2011) studied 25 healthy Persian cats, with an average age of 30 months. The average RI of the renal artery was $0.54 \pm 0.07$ and of the interlobar artery was $0.52 \pm 0.06$. The RI values obtained in this study were similar to the values reported in the literature.

Chang et al. (2010) evaluated the RI of the renal artery of 22 healthy dogs of up to four months old and 33 dogs of five months to seven years old. These authors found a negative correlation between the RI and age. Older dogs had lower values of RI $(0.65 \pm 0.05)$ than the pups $(0.75 \pm 0.05)$. The same was observed in this study, where ewes showed the lower renal artery RI compared with yearlings.

Chetboul et al. (2012) reported the frequent occurrence of azotemia in dogs with degenerative mitral valve disease due to renal hemodynamic changes. The disease was classified into three stages in 55 animals. Azotemic dogs showed RI of interlobar artery as $0.74 \pm 0.08$, and animals without azotemia as $0.62 \pm 0.05$. The RI of renal bent artery was not affected by the disease, but the RI of interlobar artery increased with the stage of the disease; $0.62 \pm 0.05$ in stage I and $0.76 \pm 0.08$ in stage III. This demonstrated that the increased RI was associated with azotemia. In this study, the sheep showed no azotemia nor RI greater than 0.70 .

Koma et al. (2006) studied the haemodynamics of canine renal and interlobar arteries in eleven healthy Beagles with severe acute, moderate chronic and mil chronic anaemia using Doppler ultrasound. The RI of renal artery were significantly higher in animals with severe acute anaemia (VG 16\%, 0.72 \pm 0.06 ), comparing with healthy animals (VG $47.5 \%, 0.66 \pm 0.07$ ), but no change was found in RI of interlobar artery. So, this Doppler parameter (RI) of renal artery demonstrated a renal haemodynamic changes associated with anaemia in dogs, which highlights the importance of this tool for systemic changes.

Hoffmann et al. (1997) described the RI of renal bent artery in five sedated horses $(0.549 \pm 0.044)$, and in seven non-sedated horses it was $0.512 \pm 0.004$. The values for this species were similar to the values in the sheep studied.

\section{CONCLUSIONS}

Ultrasonography allowed easy evaluation and measurement of the renal length in the three groups, and a standardization of renal length could be established for the sheep at different ages.

This study also showed that ultrasound is an image test that can help effectively in the diagnosis of renal disorders in sheep.

It was possible to establish values considered normal, given the solidity of the groups, the RIs of the renal and interlobar arteries in yearlings and ewes, which are close to the values already described for dogs, cats and humans.

The RI, obtained with the Doppler recourse, is another parameter that will assist in the diagnosis of diseases that cause changes in renal vascular resistence.

Acknowledgments.- The authors would like to thank "Fundação de Amparo à Pesquisa do Estado de São Paulo (FAPESP)" for financial support (Proc. 2011/01560-4) to purchase the ultrasound equipment; to Zootechnician Francisco Manoel Nogueira Fernandes, Cabanha Chico Borborema's owner, located in São Manuel/SP, for providing all the sheep for this study.

Conflict of interest statement.- The authors have no competing interests.

\section{REFERENCES}

Acorda J.A., Paloma J.C., Cariaso W.E. \& Cabrera L.A. 2009. Comparative ultrasound features of the liver, kidneys and spleen in female sheep (Ovis aries) at different ages. Philipp. J. Vet. Med. 46:26-36.

Biricik H.S., Cimtay I., Oztürk A. \& Aksoy G. 2003. B-mode and color Doppler sonography of kidneys in healthy lambs and lambs with urolithiasis. Dtsch. Tierärztl. Wochenschr. 110:5502-5055.

Braun U., Schefer U. \& Föhn J. 1992. Urinary tract ultrasonography in normal rams and in rams with obstructive urolithiasis. Can. Vet. J. 33:654659.

Calzavacca P., Evans R.G., Bailey M., Lankadeva Y.R., Bellomo R. \& May C.N. 2015. Long-term measurement of renal cortical and medullary tissue oxygenation and perfusion in unanesthetized sheep. Am. J. Physiol. Regul. Integr. Comp. Physiol. 308:832-839.

Cartee R.E., Selcer B.A. \& Patton C.S. 1980. Ultrasonographic diagnosis of renal disease in small animals. J. Am. Vet. Med. Assoc. 176:426-430.

Carvalho C.F. \& Chammas M.C. 2011. Normal Doppler velocimetry of renal vasculature in Persian cats. J. Feline Med. Surg. 13:399-404.

Chang Y.J., Chan I.P., Cheng F.P., Wang W.S., Liu P.C. \& Lin S.L. 2010. Relationship between age, plasma renin activity, and renal resistive index in dogs. Vet. Radiol. Ultrasound. 51:335-337.

Chetboul V., Daste T., Gouni V., Concordet D., Trehiou-Sechi E., Serres F., Pouchelon J.L., Germain C.A., Layssol-Lamour C. \& Lefebvre H.P. 2012. Renal Resistive Index in 55 Dogs with Degenerative Mitral Valve Disease. J. Vet. Intern. Med. 26:101-108.

El-Kammar M.H., Alsafy M.A.M., Mohammed M.I. \& El-Neweshy M.S. 2012. Ureteric obstruction and hydronephrosis in baladi goats: Topographical anatomy, ultrasonographical, hematological and pathological findings. Small Rum. Res. 104:169-178.

Ferreira D.O.L., Santarosa B.P., Belotta A.F., Mamprim M.J., Silva A.A., Dias A., Chiacchio S.B. \& Gonçalves R.C. 2014. Alterações ultrassonográficas renais e vesicais de ovinos confinados e suplementados com cloreto de amônio. Pesq. Vet. Bras. 34(Supl.1):99-106.

Figueira L.M., Fonseca J.F., Arashiro E., Souza-Fabjan J., Ribeiro A., Oba E., Viana J. \& Brandão F.Z. 2015. Colour Doppler ultrasonography as a tool to assess luteal function in Santa Inês ewes. Reprod. Domest. Anim. 50:643-650.

Finn-Bodner S.T. \& Hudson J.A. 1998. Abdominal vascular sonography. Vet. Clin. North. Am., Small Anim. Pract. 28:887-942. 
Floeck M. 2009. Ultrasonography of bovine urinary tract disorders. Vet. Food Clin. Anim. 25:651-667.

Floeck M., Aslam S., Schaetz G., Mayr E. \& Franz S. 2013. Ultrasonographic assessment of the spleen in 60 healthy sheep. N.Z. Vet. J. 61:165-167.

Hoffmann K.L., Wood A.K. \& Kirby A.C. 1997. Use of Doppler ultrasonography to evaluate renal arterial blood flow in horses. Am. J. Vet. Res. 58:697-701.

Kaneko J.J., Harvey J.W. \& Bruss M.L. 2008. Clinical Biochemistry of Domestic Animals. 6th ed. Academic, San Diego. 916p.

Koma L.M., Kirberger R.M. \& Scholtz L. 2006. Doppler ultrasonographic changes in the canine kidney during normovolaemic anaemia. Res. Vet. Sci. 80:96-102.

Lee S., Park N., Kim J. \& Eom K.D. 2014. Doppler ultrasonographic evaluation of renal arterial resistive and pulsatility indices in overhydrated Beagles. Am. J. Vet. Res. 75:344-348.

Morrow K.L., Salman M.D., Lappin M.R. \& Wrigley R. 1996. Comparison of the resistive index to clinical parameters in dogs with renal disease. Vet. Radiol. Ultrasound. 37:193-199.

Nyland T.G., Fisher P.E., Doverspike M., Hornof W.J. \& Olander H.J. 1993.
Diagnosis of Urinary tract obstruction in dogs using duplex Doppler ultrasonography. Vet. Radiol. Ultrasound. 34:348-352.

Scott P. 2000. Ultrasonography of the urinary tract in male sheep with urethral obstruction. In Practice 22:329-333.

Scott P.R. \& Sargison N.D. 2010. Ultrasonography as an adjunct to clinical examination in sheep. Small Rum. Res. 92:108-119.

Scott P.R. 2012. Clinical, ultrasonographic and pathological description of bladder distension with consequent hydroureters, severe hydronephrosis and perirenal fluid accumulation in two rams putatively ascribed to pelvic nerve dysfunction. Small Rum. Res. 107:45-48.

Scott P. 2013. Transabdominal ultrasonographic examination of 26 sheep with suspected urinary tract disease (2010-2012). J. Vet. Sci. Med. Diagn. 2:1-5.

Silva V.C., Mamprim M.J. \& Vulcano L.C. 2008. Ultra-sonografia no diagnóstico de doenças renais em pequenos animais. Vet. Zootec. 15:435-444.

Streeter R.N. \& Step D.L. 2007. Diagnostic ultrasonography in ruminants. Vet. Clin., Food Anim. Pract. 23:541-574.

Widmer W.R., Biller D.S. \& Adams L.G. 2004. Ultrasonography of the urinary tract in small animals. J. Am. Vet. Med. Assoc. 225:46-54. 